\title{
Diversity of Edible Flora and Biotourism Potential Development of Botany Adventure in Turgo, Mount Merapi National Park Yogyakarta
}

\author{
Muhammad Badrut Tamam ${ }^{*}$, Aisyah Hadi Ramadani', Heri Santoso ${ }^{3}$, Thobib Hasan Al \\ Yamini $^{4}$ \\ 12 Generasi Biologi Indonesia Foundation, Semampir, Cerme Gresik, East Java \\ ${ }^{1234}$ Department of Biology, Faculty of Science and Technology, Universitas Muhammadiyah \\ Lamongan, East Java
}

*email: mh.badruttamam@gmail.com

\begin{tabular}{l} 
Article Info \\
\hline Key word: \\
Edible plant \\
Natural adventure \\
Ecotourism \\
Recreation \\
Tracking
\end{tabular}

Article history:

Received: $20 / 02 / 2020$

Revised: 19/08/2020

Accepted: 20/08/2020

\begin{abstract}
Turgo Hill is one of the areas of Mount Merapi National Park included in the Nature Tourism Zone which is intended for recreational purposes, tourist visits, and other activities. This research activity was carried out based on a case study conducted by Generasi Biologi Indonesia (Genbinesia) in the activities of Botany Adventure in Turgo Hill. This study objectives to determine the diversity of edible flora, analyze the potential of botany adventure biotourism, and plan strategies for special interest in botanical biotourism in Turgo Hill. The research method used for the inventory of edible flora is carried out by exploring methods in 2 line transect as long as 500 meters. Analysis of potential biotourism used descriptive methods through field observationed, asked the questionnaires, and interviewed to participants. The biotourism strategy plan is compiled with the SWOT technique. The result showed that there are 60 species of edible flora found along the tracking routes Based on the analysis of potential, Botany Adventure Biotourism activities are feasible in Bukit Turgo with a feasibility index of $92.15 \%$. The highest potential is supported by the attractiveness of natural resources, accessibility, and the availability of clean water. SWOT recommends strengthening and developing external factors to improve botanical biotourism in Bukit Turgo by providing special vehicles that mobilize participants, complementing facilities, especially souvenir shops, religious facilities, other tourism facilities, and intensively promote this biotourism.
\end{abstract}

Copyright $(2020$ Universitas Islam Negeri Raden Fatah Palembang. All Right Reserved

\section{Introduction}

Indonesia is a mega-biodiversity country that has a record number of flora including 30,500 species of moss, 2,197 species of ferns and 30,000-40,000 seed plants (Widjaja et al.,
2011). The highly richness of flora in Indonesia is a source of food, medicine, clothing, shelter, and provides ecological benefits for human life (Kartawinata, 2010). However, the existence of the potential of this 
useful flora has not been maximally utilized by the community. Therefore, one effort to introduce useful flora is through biotourism education activities by explaining the various benefits of flora directly.

Exploring useful flora on the Mount Turgo Merapi National Park is the first step to find out the diversity of flora in the region. Bukit Turgo was chosen as a place for biotourism because it has the advantage of being a relatively intact forest area after the eruption of Mount Merapi in 2010 (Marhaento \& Kurnia, 2015) and including the Nature Tourism Utilization Zone (Wijayati \& Rijanta, 2020). The existence of Bukit Turgo in the administrative area of Yogyakarta Province also provides its value to improve the tourism sector based on tropical life sciences.

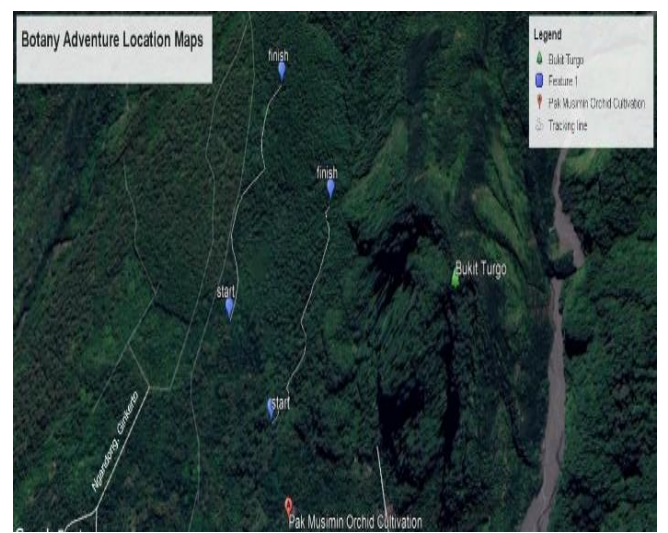

Picture 1. Botany adventure picture maps

\section{Materials and Methods}

\section{The study was conducted with a descriptive method through field observations, questionnaires and interviews to the potential aspect for biotourism. Exploration of biotourism potential carried out following the guidelines for the Analysis of Regional Operations and Attractions of Nature Tourism (ADO-ODTWA) modified from the Director General of Forest Protection and Nature Conservation (Dirjen PHKA, 2003). Questionnaire and interview respondents were Botany Adventure participants (60 people) and Turgo community leaders (2 people).}

Field observations are intended to inventory and verify the potential of the area as a biotourism area. Aspects observed based on Dirjen PHKA (2003), include (1) Biological conditions - focused on useful and edible plant species. Data was collected by tracking / cruising method (Cruise Method) (Rugayah and Pratiwi, 2004). The tracking path is divided into 2 which are determined based on elevation which are steep and gentle ramps. Each exploration tracks have 500 meter lenghts; (2) Attractiveness - the criteria assessed for the potential of forest biotourism include natural beauty, uniqueness of natural resources, abundance of natural resources that stand out, integrity of natural resources, sensitivity of natural resources, types of natural tourism activities, location cleanliness, and regional security; (3) Level of relationship or accessibility - assesses the conditions and distance of the road, and the travel time to the location; (4) Accommodation - record accommodation information available within a $15 \mathrm{~km}$ radius of the object; (5) Supporting facilities and infrastructure - observation of the availability of other facilities around the area such as public transportation, souvenir shops, road infrastructure networks, and drinking water; (6) Availability of clean water - observed in terms of volume, distance, flow, feasibility of consumption, and availability; (7) Security - considered in terms of visitor safety, potential disasters, and other activities of destruction of nature. These aspects are then analyzed by the SWOT method using scoring and weighting so that the Turgo area development strategy can be determined as a destination for biotourism

\section{Results and Discussion}

Field observations obtain biological conditions in the diversity of useful plant species along the observation tracks. As many as 60 species of edible plant species have been successfully inventoried (Table 1). The high number of edible plant species found at the two tracking lines is the initial potential value of Turgo as a botanical tourism. Flamin and Asnaryanti (2013) revealed that in order to become a botanical tourism, there are at least a key species that have an attraction for visitors. The Tahura Nipa-Nipa studied by them has 17 attractive trees. Pratama (2017) 
also states that the presence of more than 5 spesies of key plants can be said to be a good category for biotourism. The species found not only mainly as edible but also it has other uses that are very diverse among others, such as traditional medicine, industrial raw materials, animal feed, and building materials. This study found plants included in the food category with complex nutritional content called "superfood" such as Pinus merkusii (Soleil, 2012). Other important plants as a determinant of ecosystem balance such as Ficus hirta and Ficus montana. Several species also found as a medical plant as reported by Mukti et al. (2016). Turgo has great potential as a special tourist area of botanical interest with edible plant specifications based on the results of biological studies.

Another aspect that also determines the high potential of an area as a biotourism area is the attractiveness of the region. The main attractions of the area studied are natural beautifulness, natural wholeness, and the uniqueness of natural resources which will support the types of tourism activities that can be presented. In addition, the safety of locations from disasters and socially negative activities also need attention. Of course all of that is reinforced by the cleanliness of the location. Tourists will feel comfortable if the area is clean from various rubbish.
The results showed that Turgo hill has high category in this aspect with a potential value of 1020 and a potential value index of $80.95 \%$. The main attraction of the Turgo area is the history of the formation of its, which is inseparable from the history of Mount Merapi. The history of the region forms a very beautiful scenery starting from the lower side of hill slide to camping ground. We able to see the Mount Merapi, Salacca zalacca plantations, and rice fields. Bukit Turgo, according to the record, is one of the areas that was relatively not severely damaged when Mount Merapi erupted. This area is only affected by pyroclastic clouds thus eliminating tree canopies in the emergent layer but there is no fire to the forest floor. These conditions provide a high assessment of the wholeness of its natural resources. Other points with high ratings are the types of tourism activities developed and the cleanliness of the location. At present, the Turgo hill is well known as an offroad bike and motorcycle sports site called "Jurang Jero Bike". In contrast, the other tours, especially those that explore the natural resources of forests are still underdeveloped. For this reason, Botany Adventure is a pioneer activity in the development of Turgo area towards biotourism.

Table 1. Edible plant found in this study location of Turgo

\begin{tabular}{cccc}
\hline No & List of Species & No & List of Species \\
\hline 1 & Agathis alba & 31 & Melastoma sp. \\
2 & Alternanthera sessilis & 32 & Mimosa pudica \\
3 & Arenga pinnata & 33 & Murraya paniculata \\
4 & Artemisia vulgaris & 34 & Oenanthe javanica. \\
5 & Artocarpus heterophyllus & 35 & Oroxylum indicum \\
6 & Arisaema sp. & 36 & Oxalis barrelieri \\
7 & Begonia hirtella & 37 & Oxalis latifolia \\
8 & Begonia multangula & 38 & Oxalis quadrangularis \\
9 & Calamus sp. & 39 & Pangium edule \\
10 & Caliandra sp. & 40 & Pennisetum purpureum \\
11 & Cassia burmannii & 41 & Persicaria chinensis \\
12 & Centella asiatica & 42 & Pilea microphylla \\
13 & Cinnamomum verum & Pinus merkusii \\
14 & Clidemia hirta & 43 & Peperomia pellucida \\
15 & Commelina elegans & 45 & Percicaria odorata \\
16 & Commelina benghalensis & 46 & Phytolacca acinosa \\
17 & Curculigo capitulate & 47 & Piper aduncum \\
18 & Costus speciosus & 48 & Piper umbellatum \\
\hline
\end{tabular}




\begin{tabular}{lccc}
\hline 19 & Crassocephalum crepidioides & 49 & Plectranthus scutellarioides \\
20 & Drymaria cordata & 50 & Portulaca sp. \\
21 & Eryngium foetidum & 51 & Pteridium aquilinum \\
22 & Erythrina variegate & 52 & Rubus rosalis \\
23 & Euphatorium odoratum & 53 & Setaria palmifolia \\
24 & Ficus hirta & 54 & Rivina humilis \\
25 & Ficus montana & 55 & Smilax leucophylla \\
26 & Globba sp. & 56 & Smilax zeylanica \\
27 & Hydrocotyle javanica & 57 & Talinum paniculatum \\
28 & Leia indica & 58 & Tribulus terrestris \\
29 & Leucaena leucocephala & 59 & Zingiber montanum \\
30 & Melanolepsis multiglandulosa & 60 & Zingiber zerumbet \\
\hline
\end{tabular}

The value of the area's attractiveness is certainly supported by the higher supporting aspects that contribute to its potential value index number. The highest potential value is the availability of clean water (value 840 with an index of $93.33 \%$ ) followed by accessibility (a value of 775 with an index of 91.17\%). Abundant fresh water is related to the natural condition of the forest, especially the density of trees which gives rise to many water springs sources. The root of the tree will acts to bind and hold water. The high density of trees makes the roots overlap and form a large water-catchment network. Clean water supply to tourist sites such as lodging, residential houses, camping ground, toilets, and restaurants will be more good supply with the help of the construction of water supply pipe infrastructure. Accessibility to locations has a high index because the Turgo hill is easy to reach and quite close to downtown Yogyakarta, the bus terminal and the airport. Turgo Hill geographically the southernmost Merapi slope landscape. The main problem of this aspect is there is no public transportation route to the location so it requires more effort and cost to rent a motorcycle or car. Based on an assessment of the potential of ODTWA, the Turgo area can be developed towards nature and sports tourism (Adirahmanta, 2005).

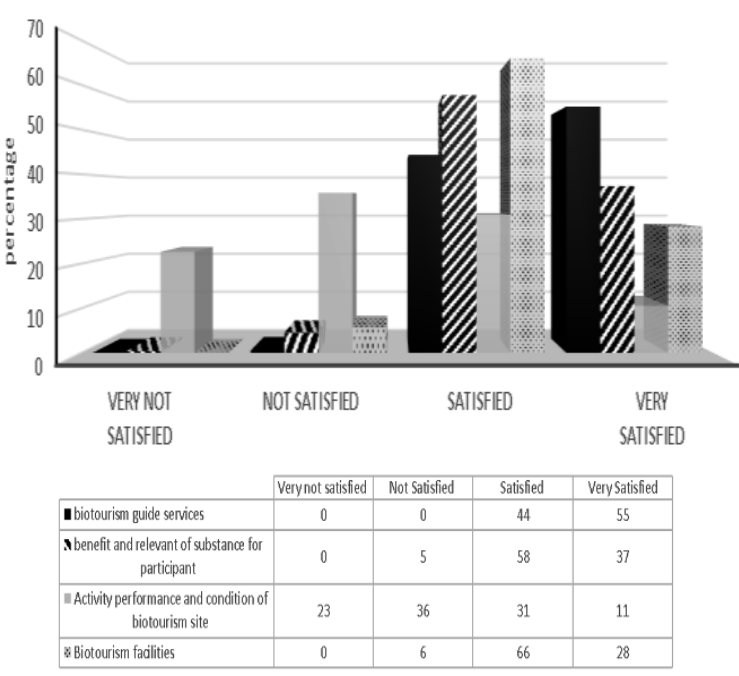

Figure 2. Percentage of participant satisfaction to Botany Adventure

Data collection on the perception of Botany Adventure participants as the pioneer to introduce the Turgo area as a special biotourism destination was carried out by questionnaire. Assessment for 4 aspects in the implementation of activities namely biotourism guiding services, the benefits and relevance of activities for participants, the form of activities and conditions of tourist sites, also service facilities. The results showed that participants were generally satisfied with the implementation of Botany adventure activities. Aspect with the highest perception of satisfaction is the service of a tour guide. This indicates the success of the guide in sharing information. Factors that determine the success of a tour guide include having a good understanding of the attractions being handled, good communication skills with participants in transferring the material, scientifically, and easily understood, polite attitude and respect 
for tour participants (Minister of Manpower and Transmigration, RI, 2009). In the Botany adventure, the tour guide also acts as a speaker who explains any useful plant species along the tracking path at the location along with its usefulness as an edible plant.

The benefits and relevance of activities have the second-highest percentage of satisfaction. This shows that the biotourism activities that are packaged in Botany Adventure provide new knowledge for participants and they have obtained material following the expectations they want. The scientific characteristics of the participants in this botany adventure are more dominated by academics, scouting survival, and botany arts practitioners.

The aspect of biotourism service facilities also gets a high percentage of satisfied categories $(66 \%)$. The facilities in the Turgo hill area have been rated well by the participants although it is still very simple buildings. Around the tourist sites there are shops café that sell souvenirs, hostel, gazebo, mosque, and camping ground. But the completeness of the souvenir stall is still very lacking. The kiosk only sells authentic coffee from the Turgo community garden with the name "Merapi Coffee," and there are no other unique souvenirs available yet. The hostel is available in the form of wooden houses that are specifically rented out to tourists, but there are several residents' homes are available for rent as hostel. Renting a resident's house as an inn becomes an additional income for the homeowner's family's economy. With this direct involvement, local community participation in tourism activities can be increased (Muallisin, 2007; Prafitri and Damayanti, 2016). The participation of local community in a tourism area very important to sustainability tourism (Setyorini, 2012). Not only these main facilities but also it is necessary to develop complementary facilities such as a reading room or a collection room for preserved specimens of plants or animals as additional attractions for visitors to develop Turgo as biotourism area.

Dissatisfaction in the aspect of activities performance and condition of the site is caused by the lack of accommodation of participants' desires in exploration activities in tracking path and number of plants described. Participants considered that the cruising path was less challenging and too short so it was not optimal in plant exploration. Criticisms of the implementation of this activity can be used as reference material for the improvement of the packaging of further activities.

Table 2. Assessment result to potential object of Turgo as biotourism area

\begin{tabular}{|c|c|c|c|c|c|}
\hline Potency & Criteria & $\begin{array}{l}\text { Potential } \\
\text { Value }\end{array}$ & $\begin{array}{c}\text { Maximum } \\
\text { Value of } \\
\text { ODTWA }\end{array}$ & $\begin{array}{c}\text { Index of } \\
\text { Potential } \\
\text { Value }(\%) \\
\end{array}$ & $\begin{array}{c}\text { ODTWA } \\
\text { Classification }\end{array}$ \\
\hline $\begin{array}{l}\text { Natural } \\
\text { attraction }\end{array}$ & $\begin{array}{l}\text { Terrestrial tourism } \quad \text { objects } \\
\text { attraction }\end{array}$ & 1.020 & 1.260 & 80,95 & High \\
\hline Supporting & Accessibility & 775 & 850 & 91,17 & High \\
\hline elements & Accomodation & 75 & 90 & 83,33 & High \\
\hline & Ammenity & 150 & 180 & 83,33 & High \\
\hline & Water sanitation & 840 & 900 & 93,33 & High \\
\hline & Security & 500 & 600 & 83,33 & High \\
\hline Total & & 3.360 & 3.646 & 92,15 & High \\
\hline
\end{tabular}

The development of biotourism in Turgo as Botany adventure was analyzed using the SWOT approach (Purnomo et al., 2013). SWOT was done based on assessment result of the biological condition, potential values, and participant satisfaction with the activities. Two components analyzed include internal factor
(IFAS) and external factor (EFAS). SWOT Mapping suggests improvements to several things for the development of biotourism in Turgo, including: (1) development of the potential of natural resources as a special biotourism that is packaged in certain tour packages such as botany adventure with 
intensive empowerment of local communities as tourism partners and training them as local guides and providers of accommodation and facilities; (2) Proposing cooperation with the management of the National Park to mantain facilities that have been built and to build supporting facilities for biotourism; (3) Provision of safety induction materials at the beginning of the biotourism activity to participants by community groups that have been trained by disaster agency; (4) Community involvement in providing local wisdom adaptation to natural disasters; (5) Self-awareness raising for tourists to maintain environmental cleanliness by not littering, and managing plastic waste; (6) Promoting special tourism through online social media and collaboration with tourism agency; (7) Submission of assistance in the provision of cleaning facilities at several strategic points in the tourist area to the environmental agency.

Direct community involvement as a local guide in safety induction and disaster adaptation is based on the cultural wisdom of the Merapi community that has long interacted with the eruption of Mount Merapi. This is a method for providing opportunities and motivation to resources that are inseparable from nature (Flamin dan Asnaryanti, 2013).

\section{Conclusion}

The result showed that there are 60 species of edible flora found along the tracking routes Based on the analysis of potential, Botany Adventure Biotourism activities are feasible in Bukit Turgo with a feasibility index of $92.15 \%$.

\section{Acknowledgment}

Researcher would like to say thank you to Generasi Biologi Indonesia Foundation as main support agency in held Botany adventure activities in Turgo, Merapi National Park for the permission letter to us conducting this research, and also all our local partner and guide Mr. Musimin.

\section{References}

Adirahmanta SN (2005) Prospek Pengembangan Kegiatan Wisata di
Kawasan Kaliurang Pasca Penetapan Taman Nasional Gunung Merapi. Tesis. Universitas Diponegoro. Semarang

Dirjen PHKA (2003) Pedoman Analisis Daerah Operasi Obyek dan Daya Tarik Wisata Alam (ADO-ODTWA). Bogor

Flamin A and Asnaryanti (2013) Ecotourism Potential and Strategy Development of Tahura Nipa-Nipa Kendari City, Southeast Sulawesi. Jurnal Penelitian Kehutanan Wllacea 2(2):154-168

Kartawinata K. (2010) Two centuries reveal the richness of Indonesia's flora and ecosystem. Sarwono Prawirohardjo Memorial Lecture X LIPI. 23 August 2013. Jakarta

Marhaento H and A. N. Kurnia (2015) Refleksi 5 Tahun Paska Erupsi Gunung Merapi 2010: Menaksir Kerugian Ekologis di Kawasan Taman Nasional Gunung Merapi. Journal of Geomatics and Planning 2(2): 69-81. https://doi.org/10.14710/geoplanning.2.2. 69-81

Menteri Tenaga Kerja dan Transmigrasi RI. 2009. Keputusan Menteri Tenaga Kerja dan Transmigrasi Republik Indonesia tentang Penetapan SKKNI Sektor Pariwisata Bidang Kepemanduan Wisata Nomor: KEP.57/MEN/III/2009. Jakarta

Muallisin I (2007) Model Pengembangan Pariwisata Berbasis Masyarakat di Kota Yogyakarta. Jurnal Penelitian Bappeda Kota Yogyakarta (2): 5-15

Mukti L PD, Sudarsono, Sulistyono (2016) Diversity of Medicinal Plant Kinds and Its Utilization in Turgo Forest, Purwobinangun, Pakem, Sleman, Yogyakarta. Jurnal Biologi 5(5) : 9-15

Prafitri G R and Damayanti M (2016) Kapasitas Kelembagaan Dalam Pengembangan Desa Wisata (Studi Kasus Desa Wisata Ketenger, Banyumas). Jurnal Pengembangan Kota 4(1):76-86

Pratama, F.W. (2017). Identifikasi Potensi dan Strategi Pengembangan Ekowisata Mangrove Pada Kawasan Wisata Tanarajae Kecamatan Labbakkang Kabupaten Pangkep. Bachelor thesis. Universitas Hassanudin. Makassar. 
Purnomo H, B Sulistyantara, A Gunawan (2013) Ecotourism Business Opportunities in The Region Sempu Island Sanctuary, East Java. Jurnal Penelitian Sosial dan Ekonomi Kehutanan 10(4):235-246

Setyorini HP D (2012) Pengaruh Faktor-Faktor Penarik Kepariwisataan Wisatawan Asal Malaysia Terhadap Keputusan Berkunjung Ke Kota Pekanbaru (Survei Pada Wisatawan Malaysia yang Berkunjung ke Kota Pekanbaru). Tourism and Hospitality Essentials Journal II (1) : 269-290
Soleil S (2012) Pine Pollen-How to Pick Your Own Superfood. Online website: https://permaculturenews.org/2012/01/04/ pine-pollen-how-to-pick-your-ownsuperfood/

Widjaja, E.A. et al. (2011) Status Keanekaragaman Hayati Indonesia. Puslit Biologi-LIPI

Wijayanti, D and R Rijanta (2020) Evaluasi Zonasi Taman Nasional Gunung Merapi. Jurnal Litbang Sukowati 3(2): 1-15. 